\title{
テーマ解説
}

\section{NEDO「イットリウム系超電導電力機器技術開発」プロジェクト における超電導ケーブルの開発}

\author{
大熊 武 $^{* 1, \dagger}$ ，大屋 正義 ${ }^{* 2}$ ，八木 正史 ${ }^{* 3}$
}

\section{Development of REBCO HTS Power Cables in "Materials \& Power Applications of Coated Conductors Project"}

\author{
Takeshi OHKUMA $^{* 1, \dagger}$, Masayoshi OHYA ${ }^{* 2}$ and Masashi YAGI ${ }^{* 3}$
}

\begin{abstract}
Synopsis: There are expectations for high-temperature superconducting (HTS) power cables as compact cables with large capacity and low-loss power transmission. Recently, the stable manufacture of many long REBCO (RE = rare-earth element) tapes has been achieved. REBCO tapes have a high critical-current density, and the AC loss resulting from the parallel magnetic field is extremely small because of the thin-film structure of the superconducting layer. The basis of the Materials \& Power Applications of Coated Conductors (M-PACC) project is to develop a process technology for fabricating REBCO tapes and promote development aiming toward the commercialization of superconducting cables using REBCO tapes. Two types of HTS cables are being developing as part of this project. These cables have superior transmission efficiency, lower loss and larger capacity than existing power cables. One is a $66 \mathrm{kV} / 5 \mathrm{kA}$ rms three-core large-current cable and the other is a $275 \mathrm{kV} / 3 \mathrm{kA}_{\mathrm{rms}}$ single-core high-voltage cable. There are several development targets. We examined factors such as AC loss, thermal characteristics of the cables under overcurrent and the optimum cable design. The cable systems of the above mentioned two kinds of cables were developed by combining the above elemental technologies and verifying the performance. This paper provides an overview of the project and describes its results.
\end{abstract}

Keywords: high-temperature superconductors, coated conductors, power cable, AC loss, overcurrent

\section{1. はじめに}

2008 年度より経済産業省から(独) 新エネルギー・産業 技術総合開発機構（NEDO）を通じて、「イットリウム系 超電導電力機器技術開発」プロジェクトにおいて、超電導 電力ケーブルに関する研究開発 ${ }^{1)}$ を実施し、2013 年 2 月 末に完了した。

本稿では、このプロジェクトで実施した研究開発の概要 を紹介する。

Received August 20, 2013

${ }^{* 1}$ 国際超電導産業技術研究センター

干113-0062 東京都江東区東雲 1-10-13

International Superconductivity Technology Center (ISEC),

1-10-13 Shinonome, Koto-ku, Tokyo 135-0062, Japan

*2 住友電気工業株式会社

干 554-0024 大阪府大阪市此花区島屋 1-1-3

Sumitomo Electric Industries, Ltd.

1-1-3, Shimaya, Konohana-ku, Osaka 554-0024, Japan

*3 古河電気工業株式会社

干290-8555 千葉県市原市八幡海岸通 6 番地

Furukawa Electric Co., Ltd.

6, Yawata-kaigandori, Ichihara, Chiba 290-8555, Japan

${ }^{\dagger}$ E-mail: ohkuma.takeshi@tepco.co.jp

\section{2. 超電導電カケーブルの開発}

超電導電力ケーブルは、コンパクトな形状で大容量送電 を可能にし、既存の電力ケーブルに比べて送電損失を低減 することが可能であることから、省エネルギー、地球温暖 化対策に貢献できることも期待されており、国内外におい て様々な検討・開発が行われている。特にイットリウム系 超電導線材（以下 $\mathrm{Y}$ 系線材）は、近年、長尺化・高特性 化等の性能向上が著しく、高電流密度・低損失などの特性 を有し、コンパクトで更なる大容量・低損失送電を可能と する超電導電力ケーブルとして期待されている。

\section{1 プロジェクトの概要}

本プロジェクトでは、 $66 \mathrm{kV} / 5 \mathrm{kA}_{\mathrm{rms}}$ 級大電流ケーブルと $275 \mathrm{kV} / 3 \mathrm{kA}_{\mathrm{rms}}$ 級高電圧ケーブルの 2 種類のケーブル開発 を行うとともに実用化に重要な要素技術の開発を行った。 本プロジェクト前半 3 カ年においては、超電導電力ケーブ ルの「大電流・低交流損失ケーブル化技術」「高電圧絶 縁・低誘電損失ケーブル化技術」「超電導電力ケーブルの 


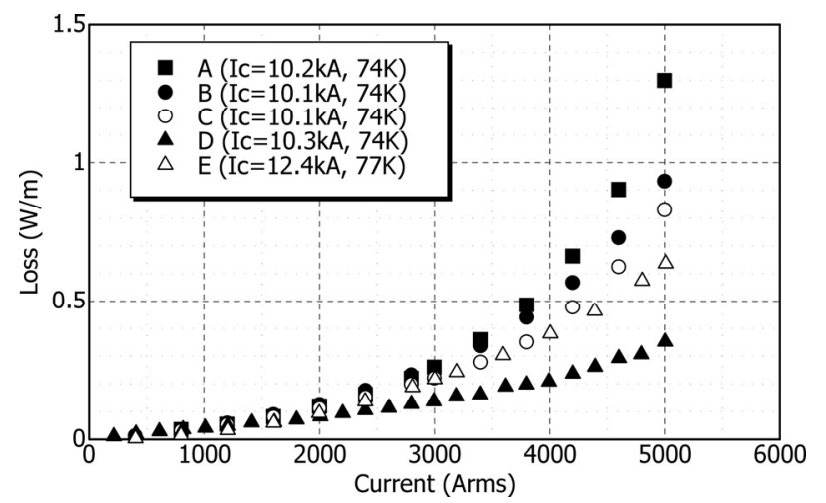

Fig. 3 Measured AC loss of the HTS conductors.

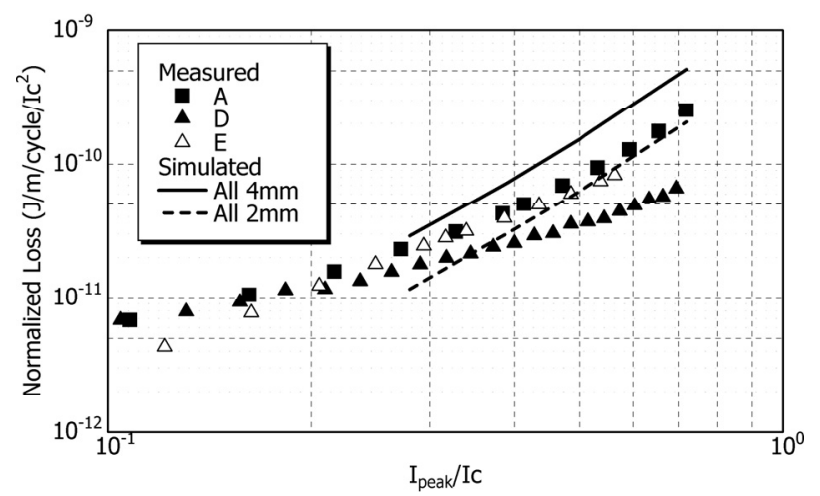

Fig. 4 Normalized AC loss of the HTS conductors.

• $2 \mathrm{~mm}$ 幅線材導体（D、E）：IBAD 線材を用いた導体 E よ

りもClad 線材を用いた導体 D の損失が低い。

各通電電流ピーク值 $\left(I_{\text {peak }}\right)$ に対する磁場分布と線材の $I_{\mathrm{c}^{-}}$ $B$ 特性を用いて計算した導体 $I_{\mathrm{c}}$ で損失を規格化した結果を

Fig. 4 に示す。なお、同図中に京都大学の数值シミュレー ション結果 ${ }^{4)}$ も合わせて示す。

·Clad 線材導体 : $4 \mathrm{~mm}$ 幅および $2 \mathrm{~mm}$ 幅線材を用いた導体

(A、D) ともに、解析結果より損失が小さい。

·IBAD 線材導体 : $2 \mathrm{~mm}$ 幅線材を用いた導体（E）は、高 負荷領域で解析結果とほぼ一致する。

本結果は、磁性基板の高透磁率特性により、内層の線材間 ギャップに起因する磁場の乱れが平滑化され、外層線材に 印可される垂直磁場が低減することで導体損失が低下する 可能性を示唆している ${ }^{5)}$ 。

\section{2 検証ケーブル製造とシステム建設}

上記 4 層導体の試作検証結果を反映して決定した $15 \mathrm{~m}$ ケーブルの設計を Table 4 に示す。銅撚り線フォーマの外 側に、超電導導体層、絶縁層、超電導シールド層、銅シー ルド層を同軸状に巻き付けてケーブルコアを形成し、3 本 のケーブルコアを撚り合わせて 1 本の断熱管内に挿入する ことで三心一括型ケーブルを製造する。

·2 mm 幅線材を用いた低損失化効果は大きいが、スリッ

卜加工の品質管理や歩留り等を考慮し、発生磁場が最も 大きい導体最外層のみに $2 \mathrm{~mm}$ 幅線材を用いるハイブ
リッド構造を採用した。なお、 $4 \mathrm{~mm}$ 幅線材には機械ス リット、2 mm 幅線材にはレーザスリットを採用した。 本設計で短尺サンプルを作製して交流損失 $1.5 \mathrm{~W} / \mathrm{m}$ phase@ $5 \mathrm{kA}_{\mathrm{rms}}(71 \mathrm{~K})$ を検証、損失目標 (2 W/m-phase 以下）を達成するとともに、 $5 \mathrm{kA}_{\mathrm{rms}}$ の連続通電試験に成 功した。

・銅フォーマと銅シールド層に短絡電流（最大 31.5 $\mathrm{kA}_{\mathrm{rms}} 、 2$ 秒）を分流させ超電導層の温度上昇を抑制する 構造を採用した。早稲田大学の数值シミュレーション ${ }^{6)}$ により銅層の必要最小断面積を決定し、サンプル試験に おいて温度上昇が想定範囲内であることを確認した ${ }^{1)}$

・電気絶縁層は、PPLP ${ }^{\circledR}$ (Polypropylene laminated paper) に液体窒素を含浸させた複合構造であり、絶縁厚 $6 \mathrm{~mm}$ のサンプル試験で要求仕様を満たすことを確認した。 ・ケーブル小径化のため、冷却時に発生する $0.3 \%$ の熱収 縮を吸収する三心コア緩み ${ }^{7)}$ は設けず、発生する約 3 ton の張力は大地に固定した両端末で把持する設計とした。 総長 $7 \mathrm{~km}$ 長の $\mathrm{Y}$ 系線材を用いて製造した検証ケーブル は Table 5 に示す出荷試験に合格し、試験サイトに向けて 出荷した。なお、検証ケーブルの端部から切り出したサン プルの交流損失測定結果（71 K）を Fig. 5 に示す。

製造したケーブルを用いて課通電試験向けケーブルシス テムを建設した。システムの構成を Fig. 6 に示す。ケーブ ル両端には終端接続部（A 端末、B 端末）をそれぞれ設け たが、B 端末では三相の導体層を容器内部で短絡し、A 端 末ではそれぞれ電流リードを介して常温部に引き出す構成 とした。なお、シールド層は両端末内部で三相短絡処理を 実施した。完成後のシステム外観を Fig. 7 に示す。

Table 4 Specifications of the $15-\mathrm{m}$ cable

\begin{tabular}{|l|l|c|}
\hline \multicolumn{1}{|c|}{ Layer } & \multicolumn{1}{|c|}{ Specification } & $\begin{array}{c}\text { Diameter } \\
(\mathrm{mm})\end{array}$ \\
\hline Former & $\begin{array}{l}\text { Stranded Cu wires with insulation } \\
\left(140 \mathrm{~mm}^{2}\right)\end{array}$ & 21 \\
\hline HTS conductor & $\begin{array}{l}\text { 4 layers, } \\
\text { REBCO wires }\left(4 / 4 / 4 / 2 \mathrm{~mm}^{\mathrm{w}}\right)\end{array}$ & 23 \\
\hline $\begin{array}{l}\text { Electric } \\
\text { insulation }\end{array}$ & PPLP $^{\circledR}\left(6 \mathrm{~mm}^{\mathrm{t}}\right)$ & 37 \\
\hline HTS shield & $\begin{array}{l}\text { 2 layers, } \\
\text { REBCO wires }\left(4 / 4 \mathrm{~mm}^{\mathrm{w}}\right)\end{array}$ & 38 \\
\hline Cu shield & Cu tapes $\left(100 \mathrm{~mm}^{2}\right)$ & 42 \\
\hline Protection & Kraft papers, nonwoven tapes & 44 \\
\hline 3 cores & Tight 3-cores stranding & 96 \\
\hline Cryostat & $\begin{array}{l}\text { Double-corrugated SUS pipes, } \\
\text { multilayer vacuum insulation }\end{array}$ & 133 \\
\hline Sheath & PVC & 140 \\
\hline
\end{tabular}

Table 5 Shipping test results of the 15-m cable.

\begin{tabular}{|l|l|l|}
\hline \multicolumn{1}{|c|}{ Item } & \multicolumn{1}{|c|}{ Results } & Comments \\
\hline $\begin{array}{l}I_{\mathrm{c}} \text { measurement } \\
\text { at } 77 \mathrm{~K}\end{array}$ & $\begin{array}{l}\text { Conductor: } 8.6 \mathrm{kA} \\
\text { Shield: } 7.2 \mathrm{kA}\end{array}$ & As designed \\
\hline $\begin{array}{l}\text { AC loss measurement } \\
\text { at } 5 \mathrm{kA}_{\mathrm{rms}}, 71 \mathrm{~K}\end{array}$ & $1.5 \mathrm{~W} / \mathrm{m}$-phase & As designed \\
\hline Structural examination & Pass & As designed \\
\hline
\end{tabular}




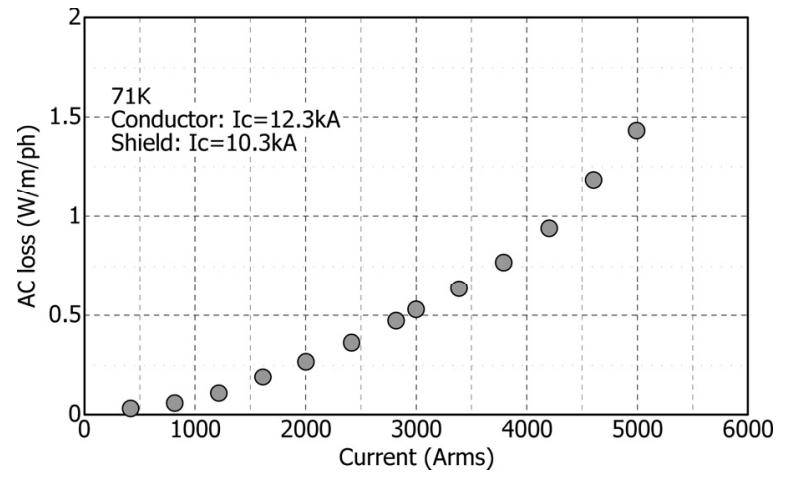

Fig. 5 Measured AC loss of the cable sample.

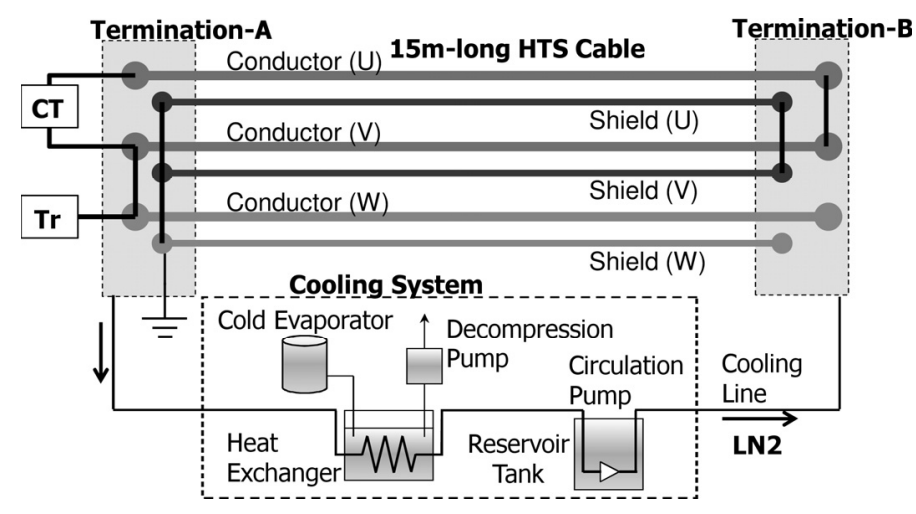

Fig. 6 Schematic view of the 15-m HTS cable system.

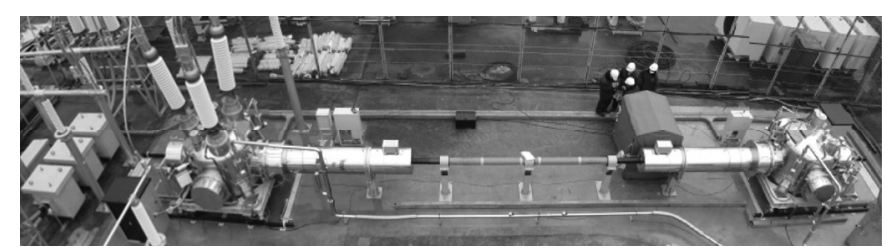

Fig. 7 15-m HTS cable system.

\section{3 システム課通電試験}

ケーブルシステムを液体窒素温度まで冷却した後、循環 冷却システムと接続して検証試験を実施した。

\section{(1) 臨界電流測定}

本試験では、長尺線路を想定した「2 コア往復通電方 式」 ${ }^{8,9)}$ を採用した。ケーブル平均温度 $77 \mathrm{~K}$ において測定 した電流電圧特性を Fig. 8 に示す。 $1 \mu \mathrm{V} / \mathrm{cm}$ 定義の $I_{\mathrm{c}}$ 值は 8 $\mathrm{kA}$ であり、往復通電時に発生する漏孔磁場による低下率 を考慮した予想值と一致し、超電導特性の健全性が確認さ れた。

\section{（2）交流通電試験}

臨界電流測定後、ケーブルシステムを交流通電装置に接 続し、Fig. 9 に示すように段階的に $5 \mathrm{kA}_{\mathrm{rms}}$ まで通電電流を 上昇させた結果、液温も安定した状態を維持し、最終的に $5 \mathrm{kA}_{\mathrm{rms}} \times 8$ 時間の通電試験を良好に完了した。なお、この

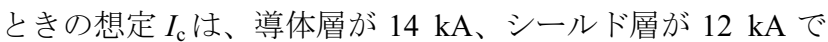
ある。 $5 \mathrm{kA}_{\mathrm{rms}}$ 通電時にケーブル部両端に発生する液体窒素

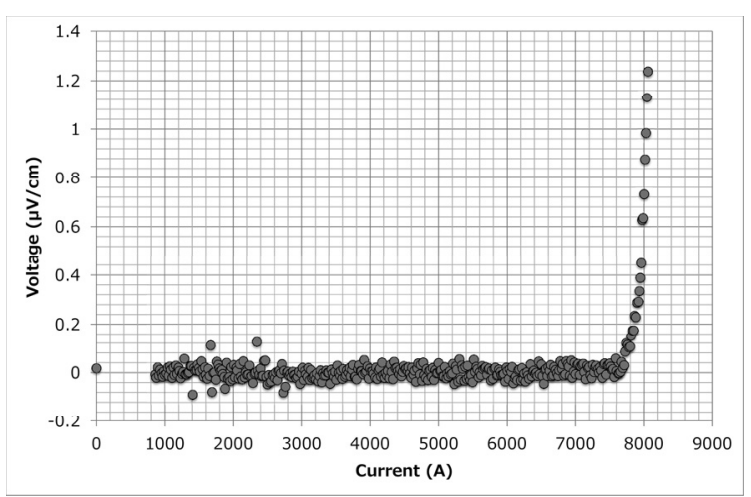

Fig. $8 I_{\mathrm{c}}$ measurement result of the 15-m cable system.

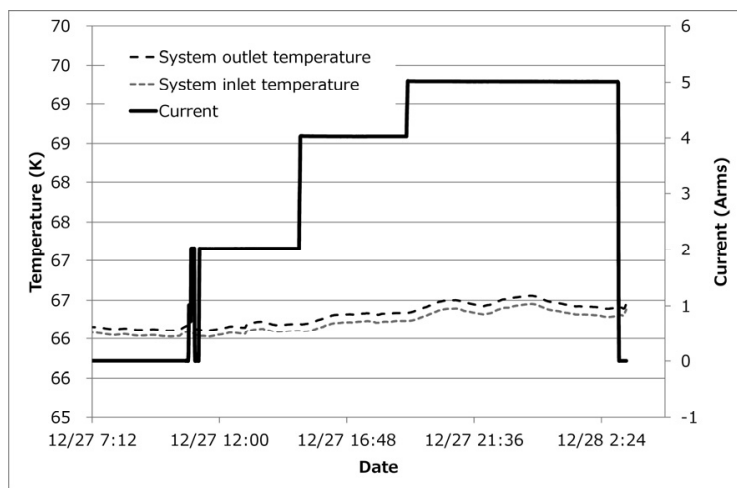

Fig. 9 AC loading test result.

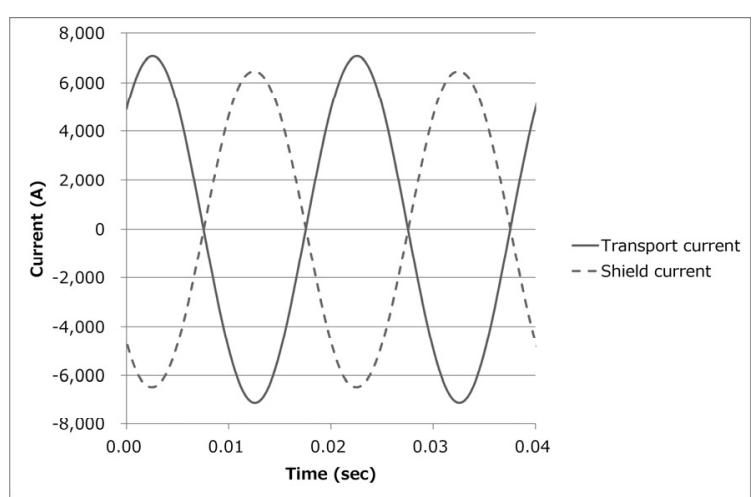

Fig. 10 Transport and shield current.

の温度差から算出した交流損失值は $1.8 \mathrm{~W} / \mathrm{m}$-phase であ り、目標值以下であることを確認した。なお、 $5 \mathrm{kA}_{\mathrm{rms}}$ 通電 時の通電電流およびシールド電流波形を Fig. 10 に示す。 シールド電流の誘導率は 91\%であり、これまでの実績と同 等の值が確認された。

(3) 長期課通電試験

ケーブルシステムを一旦昇温した後、再度冷却して臨界 電流特性を確認したが、ヒートサイクルによる特性劣化は 確認されなかった。さらに定格電圧を課電して部分放電が 発生しないことを確認した後、30 日間の長期課通電試験を 実施した。電圧は 30 年間運用に相当する加速試験条件 ${ }^{10)}$ として対地間電圧 $51 \mathrm{kV}$ を連続で課電し、同時に定格電流 


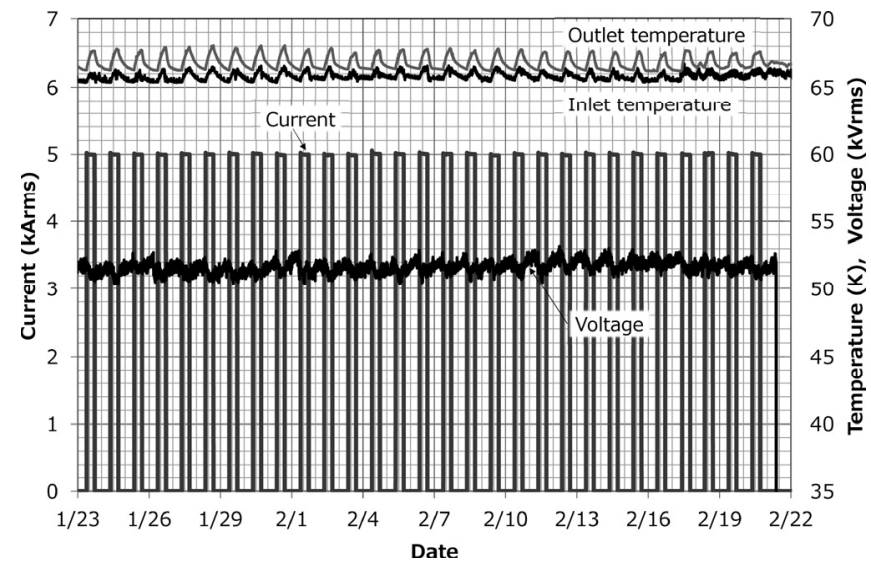

Fig. 11 Status of the long-term operation test.

$5 \mathrm{kA}_{\mathrm{rms}}$ を 8 時間オン、16 時間オフする通電サイクル試験を 行った。なお、冷却システムの運転条件は、ケーブルシス テム出口圧力を $0.2 \mathrm{MPaG}$ 以上、ケーブルシステム出口温 度を $68 \mathrm{~K}$ 以下、液体窒素流量を $40 \mathrm{~L} / \mathrm{min}$ とした。長期課 通電試験の結果を Fig. 11 に示す。試験期間中にケーブルシ ステムの温度に異常な変化もなく、30 日間の試験を良好に 完了した。

この後の課電試験において部分放電は観測されず、臨界 電流特性にも変化がないことを確認し、システム検証試験 を良好に完了した。

\section{（4）残存性能試験}

システム検証試験完了後、ケーブルシステムの解体調査 を行うとともに、切り出したケーブルサンプルの臨界電流 測定、交流損失測定、耐電圧試験 $(\mathrm{AC} 90 \mathrm{kV} \times 3$ 時間、 $\mathrm{AC100} \mathrm{kV} \times 10$ 分、 $\mathrm{Imp} \pm 385 \mathrm{kV} \times 3$ 回 ${ }^{10)}$ および構造調査 を実施して、良好な結果を得た。

今後、Y 系線材の高性能化・低損失化、冷却システムの 高効率化・低コスト化等の課題が残っており、実系統にお いてケーブルシステムの長期信頼性の実証を行っていく必 要はあるが、本プロジェクトを通じて、大電流・低損失 ケーブルの特性評価に目処をつけた。

\section{4. $275 \mathrm{kV} / 3 \mathrm{kA}$ 級高電圧ヶーブル}

高電圧ケーブル開発においては、本プロジェクト前半 3 力年の成果を生かしつつ、さらなる設計の最適化を検討 し、50 m 長のケーブル作製に生かした。全長 $50 \mathrm{~m}$ から、 $20 \mathrm{~m}$ を抜き取り、特性性能検証によって設計どおりに作ら れているかを確認し、残りの $30 \mathrm{~m}$ については中間接続部、 終端接続部を組み立てた後に、長期課通電試験を行い、実 用性を検証した。

\section{1 開発目標}

単相 $275 \mathrm{kV}, 3 \mathrm{kA}_{\mathrm{rms}}$ の電流を通電可能とする単心ケーブ ル終端接続部と中間接続部を開発し、30 m 長ケーブルシス テムにて検証試験を行う。

目標として、1 相あたりのケーブル損失は、0.8 W/m-@3
$\mathrm{kA}_{\mathrm{rms}} / 275 \mathrm{kV}$ (相電圧) 以下とする。ケーブル外径は、 $\phi 150 \mathrm{~mm}$ 以下とし、275 kV 級の電力系統で事故等が生じ た場合の過電流に耐え得る構造とする。

\section{2 耐過電流特性の向上}

前半 3 カ年で検討した超電導ケーブルは銅撚り線 325 $\mathrm{mm}^{2}$ の丸撚り導体、超電導シールドには銅編組線 $310 \mathrm{~mm}^{2}$ を使って、事故電流による過電流保護とした。その結果、 $275 \mathrm{kV}$ システムで最悪の事故ケース $63 \mathrm{kA}_{\mathrm{rms}}-0.6 \mathrm{sec}$ の過電 流に対しても耐性を示したものの、導体の温度は最大で $150 \mathrm{~K}$ と約 $70 \mathrm{~K}$ の温度上昇が観測された ${ }^{1)}$ 。上昇した後 の、温度の復帰は外側からの $\mathrm{LN}_{2}$ による冷却であるため、 $2 \mathrm{~m}$ の単尺ケーブルにもかかわらず、2 時間の時間を要し た。そこで、温度上昇を抑え復帰時間を早くするために、 中空銅フォーマ $400 \mathrm{~mm}^{2}$ を採用し、通電・伝熱特性を解析 し ${ }^{11)}$ 、試験結果と比較した。その結果、0.1 secまでは超電 導特性の臨界温度以下（90 K）であり、瞬時復帰が可能で ある。また、0.6 sec の温度上昇は実験で $20 \mathrm{~K}$ 、解析で導体 $27 \mathrm{~K} 、$ シールド $32 \mathrm{~K}$ であり、丸撚り導体の $325 \mathrm{~mm}^{2}$ の 70 $\mathrm{K}$ と比較しても低く抑えることができ、さらに復帰特性も 2 時間から 10 分以内に改善された。

\section{3 交流損失および誘電損失の最適化}

4.2 における耐過電流特性の向上は、交流損失、誘電損 失およびケーブル外径に影響を及ぼす。交流損失におい て、巻きつける外径が太くなり、使用する線材が増える。 試作した超電導導体の仕様およびを前半 3 力年の導体 (2010(3-C)）との比較を Table 6 および Fig. 12 に示す。

交流損失は、同じ $I_{\mathrm{c}}$ を持っていたとしても明らかな低減 が見られる。これは、超電導線材の本数が増えることで、 線材 1 本あたりの電流分担量が低減したためと考えられ る。 $3 \mathrm{kA}$ での交流損失は $0.124 \mathrm{~W} / \mathrm{m}$ であり、前半 3 力年の 成果の約半分になっている。さらに、測定結果は、数值解 析結果 ${ }^{12)}$ と良い一致を示している。この数值解析では、線 材幅方向の両端で、レーザによる熱影響を受けた部分を考 慮に入れて計算している。数值解析では、シールド付きの 超電導ケーブルの損失值も導出した。今までの実績から、 シールドの交流損失は導体の 1/3～1/4 と見積もれるが、

Table 6 Specifications of the two-layer HTS conductors

\begin{tabular}{|l|l|l|}
\hline & \multicolumn{1}{|c|}{$\begin{array}{c}\text { HTS conductor at } \\
2011\end{array}$} & \multicolumn{1}{|c|}{$\begin{array}{c}\text { HTS conductor at } \\
2010\left(3-C^{[1]}\right)\end{array}$} \\
\hline YBCO tape width & $\begin{array}{l}3 \mathrm{~mm} \\
\text { (after laser slitting) }\end{array}$ & $\begin{array}{l}3 \mathrm{~mm} \\
\text { (after laser slitting) }\end{array}$ \\
\hline HTS conductor & 2-layer, 61 tapes & 2-layer, 46 tapes \\
\hline Outer diameter & $35.4 \mathrm{~mm}$ & $25.5 \mathrm{~mm}$ \\
\hline$I_{\mathrm{c}}$ of the conductor & $6,270 \mathrm{~A}(77.3 \mathrm{~K})$ & $4,700 \mathrm{~A}(77.3 \mathrm{~K})$ \\
\hline & & $0.297 \mathrm{~W} / \mathrm{m}(70.0 \mathrm{~K})$ \\
& $0.124 \mathrm{~W} / \mathrm{m}(73.7 \mathrm{~K})$ & $\left(I_{\mathrm{op}} / I_{\mathrm{c}}: 0.50\right)$ \\
AC loss at 3 kA & $\left(I_{\mathrm{op}} / I_{\mathrm{c}}: 0.47\right)$ & $0.235 \mathrm{~W} / \mathrm{m}(68.7 \mathrm{~K})$ \\
& & $\left(I_{\mathrm{op}} / I_{\mathrm{c}}: 0.46\right)$ \\
\hline
\end{tabular}




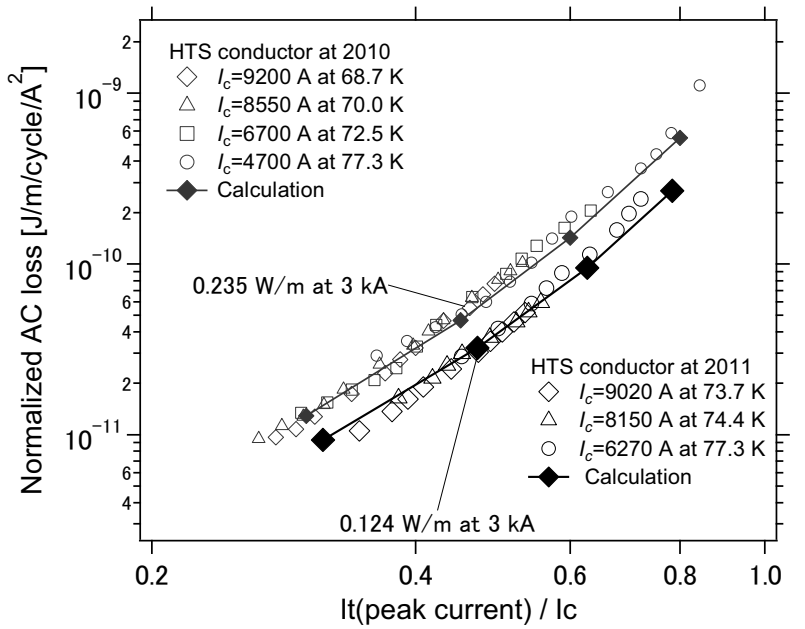

Fig. 12 AC loss characteristics of the new conductor and 3-C made in 2010.

シールドで使用している線材の幅方向の端部特性がレーザ で切断したものに比べて良くないので、シールドの損失は 高めになり、数值解析の結果では、ちょうど $0.2 \mathrm{~W} / \mathrm{m}$ と見 積もっている。

一方、ケーブル外径については、導体が大きくなること で、 $\phi 150$ を超えてしまう可能性を懸念した。絶縁ストレ スが最も高くなるのは、導体直上であるが、外径が太くな ることで、電界ストレスは下がり、絶縁厚を薄くできる。 その結果、ケーブル外径は $\phi 150$ 以内におさまる設計と なった。一方、絶縁厚を薄くすることで、静電容量は増加 するので、誘電損失は増加する。見積もられた誘電損失は $0.6 \mathrm{~W} / \mathrm{m}$ であり、前半 3 力年の $0.5 \mathrm{~W} / \mathrm{m}$ よりも大きくなっ ている。つまり、交流損失の低減分が誘電損失に転化して おり、交流損失 $0.2 \mathrm{~W} / \mathrm{m}$ 、誘電損失 $0.6 \mathrm{~W} / \mathrm{m}$ の配分で、目 標を達成できる設計とした。

\section{4 ケーブルの作製と単尺サンプルの試験結果}

製作後の仕様を Table 7 に、出来上がったサンプルを Fig. 13 に示寸。超電導導体の線材の本数が 61 本から 1 本 減らしている。線材の長手方向に線材幅のうねりがあり、 試作の結果、安全をみて 60 本とした。 $50 \mathrm{~m}$ の超電導ケー ブル製作に使用した超電導線は単長で $50 \mathrm{~m}$ 以上である。

全ての超電導線に対して、全長 $I_{\mathrm{c}}$ を測定しており，超電 導導体層用の $3 \mathrm{~mm}$ 幅の超電導線では $80 \mathrm{~A}$ 以上 (平均 97 A）、超電導シールド層用の $5 \mathrm{~mm}$ 幅の超電導線では $100 \mathrm{~A}$ 以上 $($ 平均 $117 \mathrm{~A})$ の超電導線を使用した。Table 7 で示し た仕様で $50 \mathrm{~m}$ の超電導コアを作製し、約 $20 \mathrm{~m}$ 分の試験サ ンプルを取り出して、抜き取りサンプルとして、 $I_{\mathrm{c}}$ 、耐電 圧試験，過電流試験，解体試験等に供試した。Fig. 14(a)に デモンストレーション用の $30 \mathrm{~m}$ の超電導コアを示す。Fig. 14(b)には $30 \mathrm{~m}$ 分の超電導コアに断熱管を取付けた様子を 示寸。

この超電導コアによる試験結果を Table 8 に示す。いず
Table 7 Specifications of the $275 \mathrm{kV}-3 \mathrm{kA}_{\mathrm{rms}}$ HTS cable

\begin{tabular}{|l|c|c|}
\hline \multicolumn{1}{|c|}{ Structure } & Specification & Diameter(mm) \\
\hline Former & $\begin{array}{c}400 \mathrm{~mm}^{2} \text { hollow copper } \\
\text { stranded conductor }\end{array}$ & 35.4 \\
\hline $\begin{array}{l}\text { HTS } \\
\text { conductor }\end{array}$ & $\begin{array}{c}\text { 2-layer, } 60 \text { tapes with } 3 \mathrm{~mm} \\
\text { wide and copper plated. }\end{array}$ & 79.4 \\
\hline Insulation & Thickness: 22 mm & 81.0 \\
\hline HTS shield & $\begin{array}{c}\text { 1-layer, } 43 \text { tapes with } 5 \mathrm{~mm} \\
\text { wide and copper plated }\end{array}$ & \\
\hline $\begin{array}{l}\text { Shield } \\
\text { protection }\end{array}$ & $\begin{array}{c}\text { 210 } \mathrm{mm}^{2} \text { copper tape } \\
\text { (2-layer) }\end{array}$ & 90.0 \\
\hline Protection & Insulation paper & 150 \\
\hline Cryostat pipe & $\begin{array}{c}\text { Double-corrugated pipe with } \\
\text { super insulation and PE sheath }\end{array}$ & \\
\hline
\end{tabular}

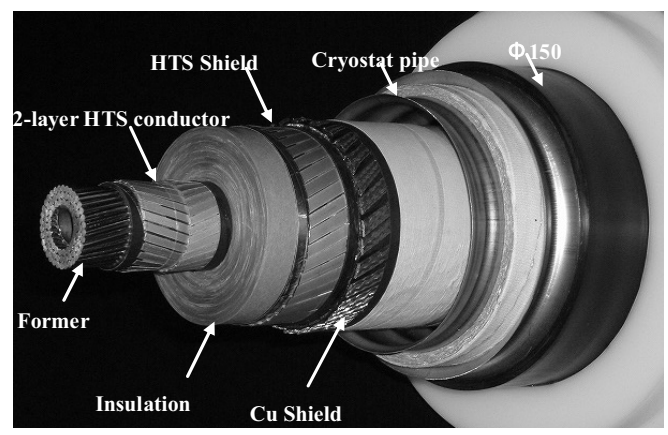

Fig. 13 Structure of the $275 \mathrm{kV}-3 \mathrm{kA}_{\mathrm{rms}}$ HTS cable.

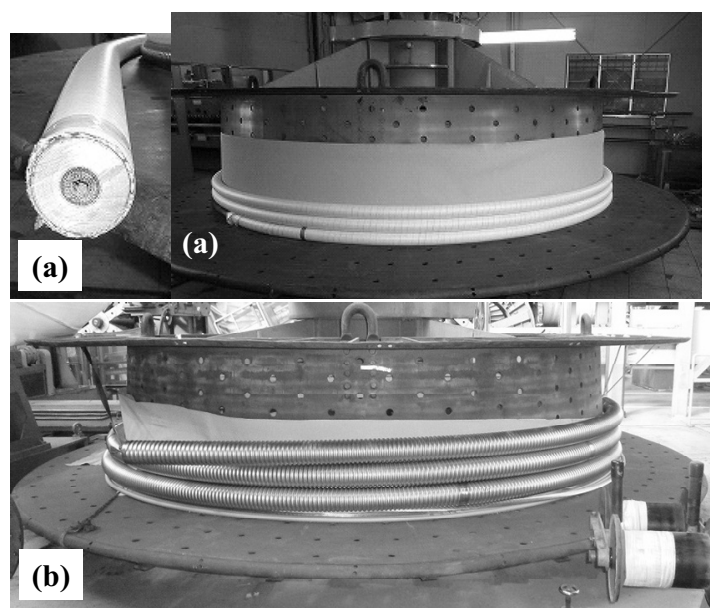

Fig. 14 (a) Fabrication of the HTS core and (b) the HTS core with cryostat pipe.

Table 8 Test results of the sample tests

\begin{tabular}{|l|c|c|}
\hline \multicolumn{1}{|c|}{ Test item } & Test results & Judgment \\
\hline$I_{\mathrm{c}}$ & $\begin{array}{c}\text { Conductor:6,440 A/ } \\
\text { Shield: } 5,800 \mathrm{~A} \text { at } 77.3 \mathrm{~K}\end{array}$ & Good \\
\hline $\begin{array}{l}\text { Partial } \\
\text { discharge }\end{array}$ & $\begin{array}{r}\text { PD free at voltage of } 310 \mathrm{kV} \\
\text { for } 10 \text { minutes }\end{array}$ & Good \\
\hline $\begin{array}{l}\text { Lighting } \\
\text { impulse test }\end{array}$ & $\begin{array}{r}\text { No breakdown at voltage of } \\
\pm 1,155 \mathrm{kV} 3 \text { times }\end{array}$ & Good \\
\hline $\begin{array}{l}\text { Withstand } \\
\text { voltage }\end{array}$ & $\begin{array}{r}\text { No breakdown at voltage of } \\
400 \mathrm{kV} \text { for } 30 \text { minutes }\end{array}$ & Good \\
\hline $\begin{array}{l}\text { Overcurrent } \\
\text { test }\end{array}$ & $\begin{array}{r}\text { No } I_{\mathrm{c}} \text { degradation after } 63 \mathrm{kA} \\
\text { for } 0.6 \text { seconds }\end{array}$ & Good \\
\hline Bending test & $\begin{array}{r}\text { No damage after bending } \\
\text { diameter of } 3 \text { meters }\end{array}$ & Good \\
\hline
\end{tabular}


れも設計どおりの性能を確認した。

$I_{\mathrm{c}}$ については大気圧の液体窒素浸漬条件で、導体側が 6440 A、シールド側が 5880 A と使用した線材の平均值に本 数をかけた期待值 5820 A と 5031 A をそれぞれ上回ってお り、製造を通しての劣化はない。耐電圧試験条件は IEC 62063、JEC-3408 などの国際規格や日本の規格やその他の 超電導ケーブル試験を参考にして定めた。部分放電 $(\mathrm{PD})$ の試験条件は、負荷遮断時や一線地絡時の異常電圧を想定 した。このときの電圧上昇倍率は $1.79 / \sqrt{3}$ であり、 $275 \mathrm{kV}$ システムの最大電圧 $300 \mathrm{kV}$ に乗じることで、 $310 \mathrm{kV}$ を導 出した。また、雷インパルス電圧は $275 \mathrm{kV}$ システムの耐 電圧值 $1050 \mathrm{kV}$ に 1.1 倍の裕度をみて、1155 kV とした。な お、耐電圧試験は参考試験として、IEC の定めている 400 $\mathrm{kV}$ とした。

\section{5 試験線路の構築と試験結果}

$30 \mathrm{~m}$ の全長試験は中国遼寧省の瀋陽市にある瀋陽古河電 纜有限公司において実施した。超電導技術は，エネルギー 需要が急速に立ち上がる東アジアにおいても注目されてい る技術であり，その中で中国での試験の実施は，日本の技 術の国際的な発信として，さらには，超電導技術の国際化 の進展に役立つものと考えて計画した。

$30 \mathrm{~m}$ ケーブルのレイアウトを Fig. 15 に示す。超電導 ケーブルは U ベンドされており，片側の終端接続部では 3 本の CV ケーブルと接続し、回路を形成している。これ は，今回の超電導ケーブルが $\mathrm{CV}$ ケーブルの 3 倍の電流輸 送ができることを示している。また、レイアウト中には中 間接続部も含まれている。

課電条件は $275 \mathrm{kV}$ システムの線間最大電圧 $300 \mathrm{kV}$ を対 地電圧に換算して $(300 \mathrm{kV} / \sqrt{3})$, さらに 30 年の劣化を考 慮した加速試験として $200 \mathrm{kV}-1$ 力月に設定した。この試験 条件には、まず式(1)の長期特性試験（V-t 試験と呼ぶ）に よる寿命指数 $n$ を導出する。

$$
V^{n} \cdot t=\text { const }
$$

ここで、 $V$ は課電電圧、 $t$ は時間となる。 $\mathrm{V}-\mathrm{t}$ 試験用の絶縁 サンプルは $1 \mathrm{~mm}$ の絶縁厚で $0.3 \mathrm{MPa}(\mathrm{abs}$.)の圧力をかけた 状態で $77 \mathrm{~K}$ を維持したサブクール状態の液体窒素に浸漬 された状態とした。その結果を Fig. 16 に示す。PDIE とは 部分放電（PD）の開始電圧（ストレス）を示しており、設 定電圧で初めて PD が観測された時間をプロットした。プ ロットした結果、寿命指数 $n$ は 80 という結果が得られ た。Fig. 17 に示すように PDIE の V-t 試験後と初期状態の を比較したところ、50\%の発生確率（PDIE ${ }_{50} ）$ が初期状態 で $26.0 \mathrm{kV} / \mathrm{mm}$ に対して、試験後は $27.3 \mathrm{kV} / \mathrm{mm}$ と良くなる 傾向を見せており、劣化は無かった。これは、液体窒素の 含浸状況の改善とも考えられるが、性能向上は $5 \%$ であ り、PDの測定感度とも考えられる。

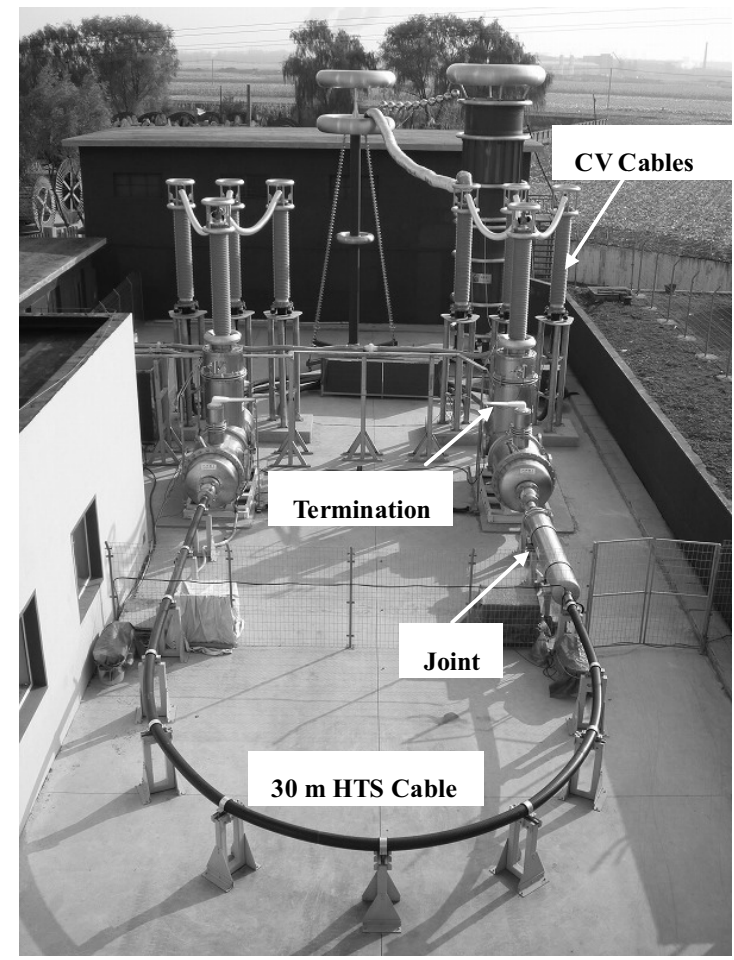

Fig. 15 Layout of the $275 \mathrm{kV}-3 \mathrm{kA}$ HTS cable.

ここで、 $V$ は課電電圧、 $t$ は時間となる。 V-t 試験用の絶縁 サンプルは $1 \mathrm{~mm}$ の絶縁厚で $0.3 \mathrm{MPa}($ abs.) の圧力をかけた 状態で $77 \mathrm{~K}$ を維持したサブクール状態の液体窒素に浸漬 された状態とした。その結果を Fig. 16 に示す。PDIE とは 部分放電（PD）の開始電圧（ストレス）を示しており、設 定電圧で初めて PD が観測された時間をプロットした。プ ロットした結果、寿命指数 $n$ は 80 という結果が得られ た。Fig. 17 に示すように PDIE の V-t 試験後と初期状態の を比較したところ、50\%の発生確率 $\left(\mathrm{PDIE}_{50}\right)$ が初期状態 で $26.0 \mathrm{kV} / \mathrm{mm}$ に対して、試験後は $27.3 \mathrm{kV} / \mathrm{mm}$ と良くなる 傾向を見せており、劣化は無かった。これは、液体窒素の 含浸状況の改善とも考えられるが、性能向上は $5 \%$ であ り、PDの測定感度とも考えられる。

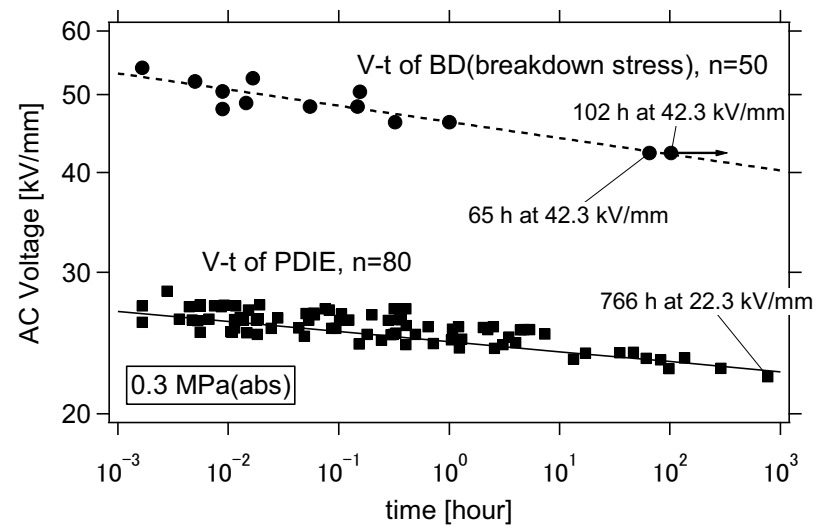

Fig. 16 V-t of PDIE for model cable (solid line), and V-t of breakdown (dashed line and circle). 


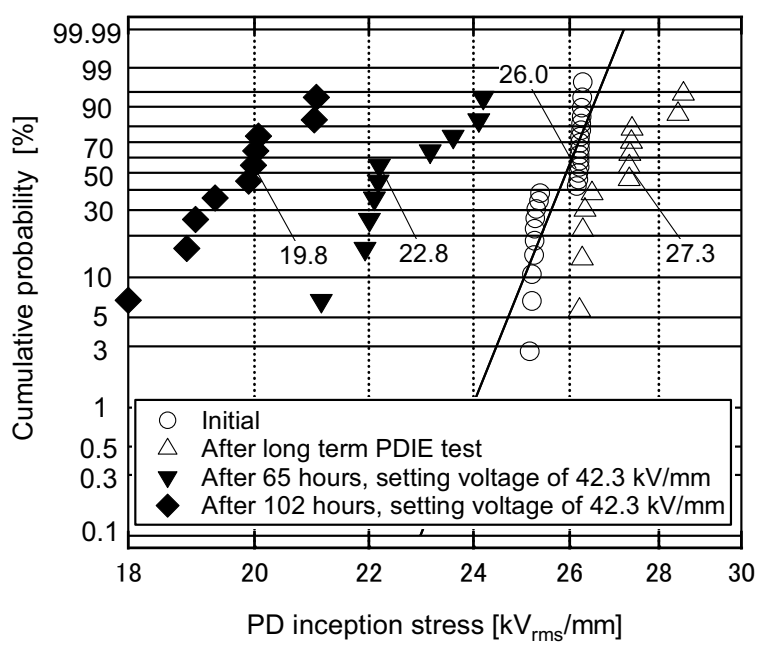

Fig. 17 Weibull plots of PDIE after the V-t tests. The insulation degradation was not observed after the V-t of PDIE, but observed after the V-t of BD.

そこで電圧を上げて、破壊（BD）の V-t 試験に移行し た。 $42.3 \mathrm{kV} / \mathrm{mm}$ の $65 \mathrm{~h}$ で破壊したサンプルがあったが、 生き残ったサンプルの $\mathrm{PDIE}_{50}$ は $22.8 \mathrm{kV} / \mathrm{mm}$ と低下してお り、その後 102 時間まで試験を継続し、破壊はなかったも のの $\mathrm{PDIE}_{50}$ は $19.8 \mathrm{kV} / \mathrm{mm}$ と明確な劣化が認められた。こ のときの寿命指数 $n$ は 50 となった。超電導ケーブルで は、運転電圧に置いて、部分放電を発生させない設計とし ているが、ここでは、安全を考え、寿命指数 $n$ を 50 とし た。長期課通電の試験電圧 $V_{t y p e A C}$ は式(2)から導出した。

$$
V_{\text {typeAC }}=\left(\frac{U_{m}}{\sqrt{3}}\right) \cdot\left(\frac{30 \text { years } \cdot 365 \text { days }}{30 \text { days }}\right)^{1 / n}
$$

ここで、 $U_{m}$ は $275 \mathrm{kV}$ システムの線間最大電圧で $300 \mathrm{kV}$ で あり、1 カ月（30 days）の試験期間では、試験電圧 $200 \mathrm{kV}$ が得られる。

定常運転試験では、本システムでの安定的な運転条件と なる平均液体窒素温度 $73 \mathrm{~K}$ 、液体窒素流量 $30 \mathrm{~L} / \mathrm{min}$ の冷却 条件で、対地間電圧 $200 \mathrm{kV}$ の課通電条件で 30 日間連続運 転を行った。通電は、 $3 \mathrm{kA}_{\mathrm{rms}}$ の通電を日中 8 時間、夜間 16 時間をゼロとした負荷変動を与えて実施した。試験は、液 体窒素を循環させて常時冷却した状態で行い、2012 年 12 月に、1 カ月の長期課通電試験を無事完了した。さらに、 長期課通電後に商用周波耐電圧試験電圧である $310 \mathrm{kV}$ を 課電したところ、部分放電フリーであることを確認して、 30 年の運転後も初期性能を持ち続けていることを確認して 試験を完了した。試験結果を Table 9 に示す。

長期課通電試験終了後、終端容器を開放して超電導を目 視観察したところ異常なく、再度、冷却して $I_{\mathrm{c}}$ が正常であ ることを確認した。ヒートサイクルに伴う、ケーブルの熱 収縮機構も設計どおりに機能している。
Table 9 Test results of the $30 \mathrm{~m}$ cable

\begin{tabular}{|l|c|c|}
\hline \multicolumn{1}{|c|}{ Test item } & Test results & Judgment \\
\hline$I_{\mathrm{c}}$ & $\begin{array}{c}\text { Conductor:6,800 A/ } \\
\text { Shield: } 7,000 \mathrm{~A} \text { at } 77.3 \mathrm{~K}\end{array}$ & Good \\
\hline $\begin{array}{l}\text { Long-term } \\
\text { tests }\end{array}$ & $\begin{array}{c}200 \mathrm{kV} \text { for } 30 \text { days, } \\
\text { current load }(3 \mathrm{kA} \text { for } 8 \text { hours } \\
\text { and } 0 \mathrm{kA} \text { for } 16 \text { hours })\end{array}$ & Good \\
\hline $\begin{array}{l}\text { Partial } \\
\text { discharge }\end{array}$ & $\begin{array}{c}\text { PD free at voltage of } 310 \mathrm{kV} \text { for } \\
10 \text { minutes }\end{array}$ & Good \\
\hline AC loss & $0.22 \mathrm{~W} / \mathrm{m}$ at $3 \mathrm{kA}$ & Good \\
\hline $\begin{array}{l}\text { Dielectric } \\
\text { loss }\end{array}$ & $0.44 \mathrm{~W} / \mathrm{m}$ at $160 \mathrm{kV}\left(\mathrm{U}_{0}\right)$ & Good \\
\hline
\end{tabular}

今後、さらに 1 年間の継続試験を予定しており、交流損 失、誘電損失を再確認する。Table 9 では、 $3 \mathrm{kA}_{\mathrm{rms}}$ 交流損 失が $0.22 \mathrm{~W} / \mathrm{m}$ 、誘電損失は $0.44 \mathrm{~W} / \mathrm{m}$ であり、目標の 0.8 $\mathrm{W} / \mathrm{m}$ 以下を達成した。交流損失については、設計の 0.2 $\mathrm{W} / \mathrm{m}$ わずかに上回る結果であり、継続試験時に液体窒素温 度との相関も含めて、再度確認する。一方、誘電損失は設 計の $0.6 \mathrm{~W} / \mathrm{m}$ よりも低くなっているが、液体窒素のサブ クール状態が強くなることで誘電損失も低くなったと推定 しているが、継続試験時に液体窒素温度との相関も含め て、確認していく。継続試験終了後に、残存試験として、 雷インパルス試験、而電圧試験を実施する。

\section{5. まとめ}

$\mathrm{Y}$ 系線材を用いた超電導電力ケーブルの開発に取組み、 $66 \mathrm{kV}$ 級大電流ケーブルおよび $275 \mathrm{kV}$ 級高電圧ケーブルの 開発を行い、システム検証試験を行った結果、ケーブルシ ステムとしての健全性が確認できた。今後は、電力機器と して求められる高い信頼性の検証を行っていくことが重要 である。

本研究は、経済産業省の「イットリウム系超電導電力機 器技術開発」プロジェクトの一環として、新エネルギー・ 産業技術総合開発機構（NEDO）からの受託により実施し たものである。

\section{参 考 文 献}

1) T. Ohkuma,: "Recent progress in the development of YBCO HTS power cables," TEION KOGAKU 46 (2001) 335-341(in Japanese) 大熊 武:「イットリウム系超電導電力ケーブルの開発状沉」、 低温工学 46 (2001) 335-341

2) N. Amemiya, et al.: "AC loss reduction of superconducting power transmission cables composed of coated conductors," IEEE Trans. Appl. Supercond. 17 (2007) 1712-1717

3) Y. Shingai, et al.: "Development of superconducting tape on textured low-magnetic-loss metal substrate," SEI Technical Review 174 (2009) 105-110 (in Japanese)

新海優樹ら：「低磁性配向金属基板を用いた薄膜超電導線材 の開発」、SEI テクニカルレビュー 174（2009）105-110

4) N. Amemiya, et al.: "AC loss reduction of multilayer superconducting power transmission cables by using narrow 
coated conductors," Supercond. Sci. Technol. 24 (2011) 0650131 110

5) N. Amemiya, et al.: "AC losses in two-layer superconducting power transmission cables consisting of coated conductors with a magnetic substrate," Supercond. Sci. Technol. 23 (2010) 0140221 8

6) X. Wang, et al.: "Numerical simulation on fault current condition in $66 \mathrm{kV}$ class RE-123 superconducting cable," Physica C 470 (2010) 1580-1583

7) M. Watanabe, et al.: "Thermo-mechanical properties of a $66 \mathrm{kV}$ superconducting power cable system", IEEE Trans. Appl. Supercond. 13 (2003) 1956-1959

8) M. Ohya, et al.: "Critical current measurement of long-length 3-inOne superconducting cables (1) -Numerical analysis-," IEEJ Ttrans. B, publication of Power and Energy Society (2011) 317

9) M. Ohya, et al.: "Critical current measurement of long-length 3-inone superconducting cables (2) -Experimental results-," IEEJ Ttrans. B, publication of Power and Energy Society (2011) 318

10) JEC-3401-2006、OF ケーブルの高電圧試験法、電気学会電気 規格調查会

11) $\mathrm{X}$. Wang, et al.: "Overcurrent characteristics of $275 \mathrm{kV}$ class YBCO power cable with hollow former", Abstracts of CSJ Conference 87 (2013) 23 (in Japanese)

王 旭東ら：「中空フォーマを用いた $275 \mathrm{kV}$ 級 YBCO 超電 導ケーブルの過電流試験特性評価」、第 87 回 2013 年春季低 温工学・超電導学会講演概要集 (2013) 23

12) N. Amemiya, et al.: "Effects of lateral-tailoring of coated conductor for AC loss reduction of superconducting power transmission cables", IEEE Trans. Appl. Supercond. 21 (2011) 943-946

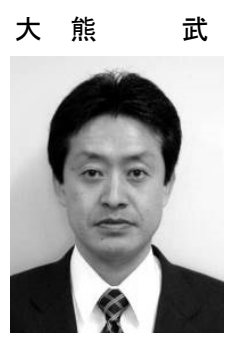

1963 年 4 月 18 日生。1988 年東京電機大学 大学院電気工学専攻修士課程修了。同年東京電 力 (株) 入社。1991 年より超電導電力機器の応 用技術に関寸る研究に従事。2010 年より (公 財) 国際超電導産業技術研究センター派遣。 2013 年より東京電力 (株) 技術統括部プロジェ クト推進グループ勤務。低温工学・超電導学 会、電気学会会員。工学博士。

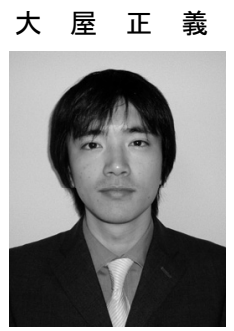

1977 年 5 月 3 日生。2006 年京都大学エネル ギー科学研究科博士課程修了。同年 4 月住友電 気工業株式会社入社。高温超電導ケーブルの開 発に従事。低温工学・超電導学会、電気学会会 員。エネルギー科学博士。

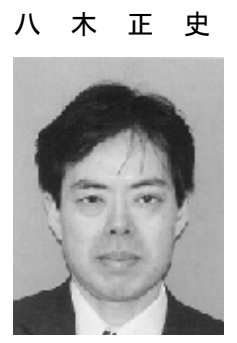

1968 年 11 月 27 日生。1994 年北海道大学 工学研究科応用物理学科修士課程修了。同 年、古河電気工業株式会社に入社。入社時よ り $275,500 \mathrm{kV}$ 電力ケーブルの施工および品質 管理に従事した。2001 年より超電導ケーブル の開発に従事しており、現在、パワー\&シス テム研究所超電導応用開発部の伝送技術グル ープマネージャ。低温工学・超電導学会、電 気学会会員。工学博士。 